\title{
Right To Information As A Means Of Protection Information Needs
}

\author{
Vitaly D. Sattarov* \\ Nina V.Stus** \\ Igor A. Goncharov *** \\ Ivan N. Kuksin **** \\ Marina V. Markhgeym
}

\section{Abstract}

This article refers to a comprehensive vision of the right to information as the main means of legal protection of the information needs of citizens in general. Based on psychological assumptions, the author justifies the importance of such needs in the life of modern society. The article details the issue of creating and guaranteeing the correct functioning of a special authorized administrative body, to act as an instance of appeal

and supervision in the course of the legal regulation of information and the underlying legal relationships. By way of conclusion, the authors especially emphasize the need to overcome the culture of secrecy, a type of undemocratic government, and refer to other requirements and accepted standards in this area to guarantee the enjoyment and enjoyment of this right at all times.

Keywords: information needs; Right to information; control and supervision of information; administrative authorities, constitutional legislation.

Perm Institute of the Federal Penitentiary Service, 125 Karpinskogo Street, Perm', 614012, Russia. Email: sattarov_@mail.ru.

** Belgorod State University, 85 Pobedy Street, Belgorod, the Belgorod region, 308015, Russia. Emai: stus@bsu.edu.ru.

*** Northern Caucasian branch of the «Russian state University of justice», 187/1 Levanevskogo Street, Krasnodar, 350002, Russia. Email: kafedragpd@yandex.ru.

**** Moscow city pedagogical University, Building 1, malaya Pirogovskaya str., Moscow, 119991, Russia. Email: PROFFKUK-1944@YANDEX.RU.

***** Belgorod State University, 85 Pobedy Street, Belgorod, the Belgorod region, 308015, Russia. Email: markheim@bsu.edu.ru. 


\title{
Derecho a la información como medio de protección de las necesidades de información
}

\begin{abstract}
Resumen
Este artículo se refiere a una visión integral del derecho a la información comoel principal medio de protección legaldelasnecesidades deinformación de los ciudadanos en general. Basado en presupuestos psicológicos, el autor justifica la importancia de tales necesidades en la vida de la sociedad moderna. El artículo detalla la cuestión de crear y garantizar el correcto funcionamiento de un organismo administrativo especial autorizado, para actuar como instancia de apelación y supervisión en el curso de la regulación legal de la información y las relaciones legales subyacentes. A modo de concluison, los autores enfatizan especialmente en la necesidad de superar la cultura del secreto, tipa de gobiernos poco democráticos, y hacen referencia a otros requisitos y estándares aceptados en esta área para garantizar el goce y disfrute de este derecho en todo momento.
\end{abstract}

Palabras clave: necesidades de información; derecho a la información; control y supervisión de la información; autoridades administrativas, legislación constitucional.

\section{Introduction}

In 1954, a renowned American academic, A. Maslow, proposed the theory according to which all human needs are distinguished by a strictly organized, hierarchical structure consisting of five levels. Each level corresponds to specific needs, their groups, among which are physiological needs for security, love, respect, self-actualization (Maslow, 1970).

Although this theory has gained resonance among the public and has become popular in certain circles, it has been actively criticized by various kinds of scholars. Among the shortcomings of the work, it was pointed out that the author was not able to reflect the whole range of existing, objectively necessary needs of people.

In his later works, A. Maslow had to take into account certain critical statements about his theory, supplement it with two more levels, types of needs: cognitive and aesthetic. At the same time, cognitive needs are the needs aimed at obtaining new information by a person and its subsequent use (Maslow, 1970).

It is important that according to the theory of the author, cognitive needs are only at the fifth level, hierarchically allowing for the needs for love, respect, safety, and satisfaction of physiological needs. If at the beginning 
Vitaly D. Sattarov, Nina V. Stus, Igor A. Goncharov, Ivan N. Kuksin y Marina V.

Markhgeym

84

Right To Information As A Means Of Protection Information Needs

of the second half of the 2ОTH century this situation of informational needs corresponded to the reality, then at present it can be called into question.

The widespread informatization of society is the cause of significant changes in the psyche of people, which are so large that they even transform the organization of the brain. In particular, according to the hypothesis suggested by G. Small and G. Vorgan, being influenced day to day by modern technologies, new neural connections responsible for adapting to the conditions of an excess of information are formed in human brain (Smoll \& Vorgan, 2011).

In the absence of access to information, people begin to feel severe discomfort, which is manifested more strongly when the information balance is destroyed and the amount of incoming data is sharply reduced. In the last decade, the experiments related to sensory deprivation have become popular. For example, a group of Russian scientists suggested the subjects putting on light-scattering glasses, soundproofing headphones and sitting motionless for 15 minutes, thereby completely depriving the subject of access to any visual and audio information (Kokorina \& Gordeeva, 2010).

The results of the experiment show that even with such a short-term restriction of the information flow, a person will experience emotional and physiological changes, including anxiety, paranoia, a weakening of the sensation of their own body, and a decrease in the supply of strength and activity (Kokorina \& Gordeeva, 2010).

The above confirms that the value of information needs for human life and health is significantly higher than that assumed by A. Maslow. According to our assessment, they should occupy the second level of the hierarchical structure of needs, second only to the physiological, or should be at the same level with thelatter.

The priority of informational or physiological needs substantially depends on external conditions. In an extreme situation in which a person is wrestling for a living, food needs, drinking, sleep will objectively prevail, but in everyday life, these groups of needs are equally necessary for the individual to survive. In fact, they should be considered as two sides of being, as spirit and matter, which are opposite, but identical in value, poles of a single substance.

Under these circumstances, the satisfaction of information needs is obligatory and will require the provision of appropriate legal protection, based on the consolidation in the national legislation of the right to information as an initial means, an instrument for regulating the sphere under consideration. 


\section{Methods}

This study involves the use of a wide range of general scientific and special methods of cognition, which is due to the purpose of the work, which is to disclose the right to information as an important means of protecting the information needs of citizens, its features, models, and the requirements for it.

So, the comparative legal method seems to be the key for this work, as it allows comparing different models of protecting the right to information and identifying their specific, common features, drawing conclusions regarding the likely directions of development of the law being studied, and increasing the efficiency of meeting the information needs of citizens.

The formal legal method was used to study the doctrinal aspects of the right to information and to form a conceptual, categorical apparatus of this work, and it was applied to develop a classification of protection models for the law under study.

Such general scientific methods as analysis, synthesis, induction and deduction accompany all stages of work, are the basis of the vast majority of reasonings and conclusions of this study.

\section{Results and Discussion}

At the international level, the right to information is positioned exclusively as universally recognized and obligatory. This fact is confirmed by the enshrining of this right in the Universal Declaration of Human Rights (Article 19), the European Convention on Human Rights (Article 10), the International Covenant on Civil and Political Rights (Article 19), the American Convention on Human Rights and others significant international sources.

In national legislation, the studied law is often established at the constitutional level, which allows pointing to its special role and high importance for regulating public life. Moreover, various constitutions contain such constructions of this law, which are similar in certain aspects, but differ in certain specific features.

In the vast majority of countries, the right to information has the form of a list of positive legal opportunities protected by law.

These lists are largely identical, but a number of specific features should be highlighted. For example, Czech citizens have the right to "perceive" 
Vitaly D. Sattarov, Nina V. Stus, Igor A. Goncharov, Ivan N. Kuksin y Marina V.

Markhgeym

86

Right To Information As A Means Of Protection Information Needs

information, while the Portuguese have the right to "receive it". Such powers are uncharacteristic of the right to information, since the reference to them is not found in any other laws or international legal acts on the topic under study.

Meanwhile, based on the etymology of the above concepts, it can be assumed that "to gain" means to "search", while "perception" of information is its assimilation or receipt. At the same time, the need for constitutional establishment of the power of "perception" seems to us unnecessary since a person will perceive information regardless of the presence or absence of a legal norm.

A number of states, such as Germany and Estonia, contrary to the given practice, have chosen to refuse to give a detailed listing of information competencies at the level of constitutions, which indicate only the ability of everyone to receive information. Nevertheless, the empowerment of citizens of these countries with information powers is based on the laws that specify constitutional norms.

For example, in accordance with the German law on freedom of information of September 5, 2005, every German has the right to access information of federal authorities, information is provided upon request of a citizen within a month, upon violation of the right it is allowed to apply for protection to the Federal Commissioner for Freedom of Information (Kugelmann, 2007).

Taking into consideration that normative legal acts aimed at disclosing and concretizing the studied law are widespread throughout the world and adopted in more than 90 countries, we can conclude that there are two main models for protecting information needs: constitutional and legislative.

Within the framework of the first model, the constitution has the most significant role in determining the list of specific information opportunities, and in the second it is the information law. The constitutional model is used more often, while the choice of its analogue is often determined by the presence of weighty grounds. For example, in Great Britain the second model is used due to the lack of a written constitution.

However, raising the issue of the English system of protecting the right to information, one should take into account its features. In view of the fact that the unwritten constitution of the named country consists of various sources, including some statutes, it will naturally raise the question of the status of the UK Law on Freedom of Information, adopted by the British Parliament in 2000.

For comparison, in the practice of individual countries, the right to information is guaranteed in law which is constitutional. An illustrative example is Sweden and its act on Freedom of the Press of 1766 (Mendel, 
2008). In our opinion, this status should not be given to English law, despite the fact that they have settled similar social relations.

The difference between these laws is in the historical significance that they have had on the development of the country and the legal awareness of its population. While the English law aimed at meeting modern standards of the rule of law in the information sphere has been recently adopted, the Swedish law was introduced not only 234 years earlier, but also turned out to be the historically first legal act that laid the foundation for the protection of information requirements, to significantly influence the legal consciousness of citizens of the Scandinavian states in the studied area.

The commitment of a number of countries to the legislative model of protection is explained by the age of the basic law. Based on the reason that information rights and freedoms have gained relevance relatively recently, in modern and recent times, the most ancient constitutional legal acts do not reflect the list of information powers.

In particular, according to R. Peled and Y. Rabin, one should pay attention to an interesting fact, that of the 18 member states of the Council of Europe that do not contain articles on the right to information in their constitutions, all but Serbia and Bosnia-Herzegovina are "veterans of democracy" (Peled \& Rabin, 2011).

Emphasizing a third, judicial, model of protecting information needs is impractical because of its narrow distribution, as well as the fact that lawmakers, as a rule, show a desire to fill the gaps in the regulatory framework, as happened in South Korea.

It should be noted that some constitutional acts especially focus on the forms, means, or methods of carrying out informational actions. So, according to the Georgian Constitution, the receipt, dissemination of information is possible in oral, written or other form. Citizens of Spain are able to exercise similar legal opportunities in any form, while the citizens of Ukraine have the right to realize them verbally, in writing, or in any other way at the choice of an interested person.

In general, the provision of the right to the population to independently determine the forms of satisfying information needs, subject to the interaction with state authorities, should be considered as a standard for progressive legislation in the field under study. The latter conclusion is confirmed by the model law "On the Right to Access to Information" adopted by the resolution of the Interparliamentary Assembly of the Commonwealth of Independent States on April 14, 2004, Issue 23-14 (Model'nyj zakon, 2019). This document contains a recommendation to participating countries to provide citizens with information either orally or in writing, or through the use of electronic data transfer technologies. 
Vitaly D. Sattarov, Nina V. Stus, Igor A. Goncharov, Ivan N. Kuksin y Marina V.

Markhgeym

88

Right To Information As A Means Of Protection Information Needs

The right to information is called upon to guarantee the free exercise by persons of their positive legal capabilities in order to satisfy information needs, but the law under investigation is not limited to this content. It also makes it possible to demand that other persons refrain from creating obstacles in the course of citizens exercising information powers, and gives them the right to seek protection in case of violations in the field under study.

It follows from the foregoing that the structure of the law in question, in addition to the possibilities for committing positive actions, includes the right to claim and demand, which is characteristic of subjectiverights.

It is important that the above elements of the right to information are associated with significant obstacles to the proper satisfaction of the information needs of each person, society on the whole. The search for the causes of such obstacles, as well as the ways to overcome them, is the subject of active discussion in many countries, including theUK.

For example, in B. Worthy's judgment, the underlying difficulties are based on an entrenched culture of secrecy and strict information control, which leads to the fact that state authorities intend to create obstacles for citizens to receive and use information using various methods, including procrastinating the response time to information requests and finding illegal reasons to refuse to reveal information, or to establish an excessively high fee for their provision (Worthy, 2007).

The latter is characteristic of Israel, in which an official information request will cost citizens an average of $\$ 22$, although the response received is often excessively concise, unclear, inconcrete, vague, which, together with regular delays in the direction of even these limited information, significantly interferes with the implementation of the investigated law and requires appeal to the courts to protect it.

According to S. Coliver, the government of many countries provides information rather randomly, there are the cases when different citizens receive different answers to the same question, while 47 percent of information requests are not considered at all (Coliver, 2006).

The demonstration of the desire for excessive secrecy is also considered to be the lack of due attention to solving the problems of legal education in the information sphere, the use of repressive measures against persons who have requested information. The dissemination of these violations in the practice of some countries is often reported by international human rights organizations such as ARTICLE 19 (Asia Disclosed, 2015).

We believe that in order to prevent violations of information rights and freedoms of man and citizen, national laws governing social relations in the field of research should provide for a system of interrelated mechanisms 
that in the aggregate will eradicate the culture of secrecy. In particular, these mechanisms include developing public control, improving the qualifications of civil servants, increasing the amount of information posted on publicly available resources on a proactive basis (that is, prior to its request by an interested person).

Among the most effective means of preventing crime in the sphere of information is the creation of a developed system of appealing against illegal decisions, actions of state bodies and their officials, which will allow the interested parties to decide the difference not only in court but also administratively. For this purpose, special state bodies with administrative and jurisdictional powers should be created.

According to T. Mendel, progressive national laws stipulate that disputes about the right to information should first be considered in independent and protected from political interference administrative instances and only after that in the courts if the parties are not satisfied with a result (Mendel, 2008).

In view of the fact that administrative authorities are able to make a decision in a matter much faster and at lower cost, the above procedure can be regarded as a successful alternative, which will protect violated rights to a wider segment of the population, including those who experience hardships.

Meanwhile, it should be borne in mind that the effective implementation by these bodies of the functions of the appellate court will require that they be given wide powers, including providing them with the right to conduct an investigation, request documents and other evidence, analyze them, and make binding decisions. As a general rule, they have the right to require officials to disclose illegally concealed information, to appoint compensation to the injured citizen.

A very common situation is when the competence of the bodies under investigation includes not only the consideration of appeals and other complaints of interested parties, but also the supervision of executive authorities. A number of countries even give such authorities the right to levy fines for violations of information law and bring officials to disciplinary liability, which is typical, for example, in India or the United States (Mendel, 2008).

The stated practice is justified by the fact that compliance with the legislation in the field of information requires regular verification, periodic monitoring, which is determined by the rapid pace of change in the technological conditions for the implementation of positive legal opportunities in relation to the search, production, exchange and dissemination of information between participants in public relations. 
Vitaly D. Sattarov, Nina V. Stus, Igor A. Goncharov, Ivan N. Kuksin y Marina V.

Markhgeym

90

Right To Information As A Means Of Protection Information Needs

\section{Conclusion}

The satisfaction and protection of the growing information needs of citizens should be recognized as a significant problem, the solution of which will be impossible without the use of legal means to exert a regulatory influence on existing public relations.

The most significant legal measure for protecting these needs is the right to information, which lays the fundamental foundations for the implementation of positive legal opportunities in the field of information. In this case, it is advisable to single out a number of general models for the protection of the investigated law, including legislative and constitutional.

Based on the state's membership in a particular model, it can be concluded as to which regulatory legal act will be crucial in determining a specific list of citizens' information powers, a constitution or a law. At the same time, both models can be quite effective and protect an approximately identical list of positive legal opportunities.

The distribution of the above models is mainly associated with the features of the historical development of states, the time of approval of constitutional legal acts and the recognition of information rights and freedoms. The countries of the constitutional model should include the majority of the states of the world, while the legislative model has become widespread in Great Britain, Norway, the United States of America, Luxembourg, and a number of other countries.

The effectiveness of the protection of the law under study and the completeness of satisfying a person's and citizen's information needs depends on the conformity of national legislation with generally recognized international requirements, standards, which include the possibility of choosing forms of information interaction and the efforts of the state towards overcoming a culture of secrecy, provided co-building, ensuring the proper functioning of a special administrative body being competent to consider appeals against legislation on information and to supervise in the field of research.

This body may have exclusive competence, be specially created to perform the above functions, and also be formed by expanding the powers and competence of an existing state body. The latter method is characteristic of developing countries. 


\section{Bibliographic References}

ASIA DISCLOSED. 2015. A Review of the Right to Information across Asia. Free Word Centre. London, Ingland. 65 p.

COLIVER, Sergey. 2006. The importance of the right of access to information held by public authorities, and the need for the united nations to take steps to further elaborate, codify, protect and promote this right. UN Conference on Anti-Corruption Measures, Good Governance and Human Rights Warsaw, 8-9 November, P. 1-10.

KOKORINA, Vladimir Antony; GORDEEVA, O.V. 2010. Kratkovremennaya sensornaya deprivaciya kak metod izucheniya aktualgeneza izmenennyh sostoyanij sozna-niya. In: Eksperimental'naya psihologiya $\mathrm{v}$ Rossii: tradicii i perspektivy, pp. 511-515. (In Russian).

KUGELMANN, Demitry. 2007. Gesetz zur Regelung des Zugangs zu Informationen des Bundes (Informationsfreiheitsgesetz-IFG): Kommentar.

MASLOW, Abraham.1970. Motivation and Personality (2ND ed.). Harper \& Row. Nueva York, USA, 395 p.

MENDEL Toby. 2008. Freedom of Information: a Comparative Legal Survey. UNESCO. Paris, Francias. 182 p.

MODEL'NYJ ZAKON. 2019. «O prave na dostup k informacii». Available online. In: http://docs.cntd. RU/DOCUMENT/901912337. Consulted on: 30/09/2019. (In Russian).

PELED, Roy; RABIN, Yoram. 2011. The Constitutional Right to Information. Columbia Human Rights Law Review. New York, USA. Pp. 357-401.

SMOLL, George; VORGAN, G. 2011. Mozg onlajn. CHelovek v epohu Interneta. Per. s angl. B. Kozlovskogo. M.: KoLibri, Azbuka-Attikus, 352 s. (In Russian).

WORTHY, Mikhail. 2007. Freedom of Information in Britain: Lessons From Australia. Alternative Law Journal, P. 229-332. 